\title{
CULTURAL HERITAGE OF A POSTER: COMMUNICATIVE AND CREATIVE EXPERIENCE
}

\author{
Svitlana Valeriivna PRYSHCHENKO (D) \\ National Academy of Government Managerial Staff of Culture and Arts, Institute of Design and \\ Advertising, Department of Graphic Design, 01015 Lavrska str. 9, bild. 15, Kyiv, Ukraine
}

Received 29 April 2020; accepted 14 September 2020

\begin{abstract}
This study contributes to the history of poster connected with interdisciplinary conceptualization, where poster is examined as a design object and core advertising medium in the context of cross-cultural interaction, cultural integration and national identification. Artistic and stylistic features of famous poster schools (Swiss, German, Austrian, Polish, Japanese, French, Italian, Baltic, Ukrainian, etc.) are analyzed and theoretically summarized on the example of cultural-imagery and tourist posters from different countries. Communicative and aesthetic aspects of image creation are presented in socio-cultural dynamics according to certain stages of social development. Colour is highlighted as the most important and attractive means among compositional factors. Scientific novelty of this study is to justify the world's cultural heritage of poster. It is proved that poster actively shapes public consciousness and has a powerful influence on public opinion. Also, poster is included in social sign system and represents past or present creative experience. Semantic role of poster is a visualization of relevant idea, general rendering of advertised object in visual form and content, perfect reflection of real or imaginary objects and phenomena in mind. The results of study indicate that present-day poster, as a product of culture should have accentuated aesthetics, non-standard vision, and variability of graphic communication and be interesting for the target audience. As advertising often borrows images from different arts, their creative interpretation and preservation of symbolic meanings are of great importance. Particular attention is focused on the relationship between art imagery and functionality in the process of poster designing.
\end{abstract}

Keywords: advertising communications, art imagery, creative interpretation, poster designing, stylistics, visual semantics.

\section{Introduction}

Research on the relationship between design and culture to enhance interdisciplinarity and diversity of projects is becoming increasingly relevant. The design today is a manifestation of culture, taking into account the creative experience of the past in order to develop the future, combining traditions and innovations, analyzing cultural, social, economic, technological and industrial changes.

\footnotetext{
*Corresponding author. E-mail: akademiki@ukr.net
} 
Being an egalitarian and common by nature poster has always occupied an important place in the fields of culture, commerce and industry of many countries. Therefore, the relevance of this topic is a study of poster in the context of image, communicative and creative experience. At the beginning of 21st century, significant changes in the conception of design and advertising occurred connecting with the processes of globalization and simultaneous ethno-cultural identification, hyper-consumption and parallel decline in the cultural level of society. Significant social changes have taken place due to the development of technologies that have led to the emergence of humanistic universal design ideas about "goods for all and everyone". Poster plays a significant role in all these changes promoting concepts, culturalartistic events or goods on the mass market. In the context of socio-cultural transformations, visual language of advertising communications was modified reflecting dramatic changes in value orientations and aesthetic tastes of society. Nowadays, advertising is a powerful industry, and poster retains its value as the main advertising medium.

The purpose of the article is to uncover the art-stylistic features of poster based on systematization and classification of visual means of advertising, depending on historical, cultural, political, economic and technological stages of the development of society. According to the purpose, the following interrelated tasks are defined:

1) to establish patterns of visual (colour-graphic, technical and semantic) means applied in the poster designing;

2) to investigate the influence of art and ethno-art traditions on poster style.

\section{Methodology and theoretical framework}

The scientific approach in total, and in particular to the classification of poster, the author understands as a way of design thinking and a way of knowing, and the methods of research as certain algorithms, certain systematic steps to achieve the specific goal - a theoretical generalization of visual advertising information. This study was used the interdisciplinary approach and comparative, socio-cultural, axiological, art-critical methods also.

\section{Results of the research}

\subsection{Poster as a product of the culture}

Scientific novelty of this study is to the retrospective review of poster and the justification of its importance as a world cultural heritage. It is proved that the poster actively shapes mass consciousness, is included in the social sign system, has a powerful influence on public opinion, represents the past or present communicative and creative experience. The semantic space of poster is a visualization of meaningful idea, a generalized rendering of reality in art visual form and content, an information about product, a perfect reflection of material or imaginary objects and phenomena.

The object of our research - the cultural heritage of a poster.

The subject of research - the evolution of visual means and stylistics of poster schools. 
Advertising poster genesis as a form of socio-cultural communication is shaped by a number of factors, among which the main determinants are:

- pragmatic, based on existing product-economic relations, development of communication channels and specific business objectives;

- cultural, influenced by socio-cultural realities of particular forms of social systems and national-psychological aspects of mental groups;

- aesthetic, determined by ideological platforms and historical processes of social development that affected transformation of social structures, spiritual and substantial culture, as well as artistic styles formation (Pryshchenko, 2018, p. 43).

Advertising with its main commercial function is recognized as a cultural phenomenon (Nerdinger, 1991; Culture.pl, 2020) since visualization becomes a logical reflection of sociocultural state of society in definite periods. Let us examine this phenomenon through a brief historical insight illustrated by poster, which development is closely connected to printing. In the 17 th century, the era of printed theater poster was coming due to Kyiv-Mohyla Academy theater and court theaters of Russian Empire were widely publicized. Later, posters were created for church dates, cultural events, masquerades and folk festivities. Peter the Great also distributed print media among common people. The number of newspapers, printed leaflets and advertising posters increased. Illustrative accompaniment had strong national specifics at that time.

France was a leader in the genre of multicoloured lithographic poster, which was included in the history of the world art. Famous artists, such as Jean Ignace Isidore Gérard Grandville, Paul Gavarni, Gustave Doré, Henri de Toulouse-Lautrec, Eugène Grasset, Pierre Bonnard, Jules Chéret focused on poster creation. Chéret is considered to be a pioneer in new genre because he has identified and implemented the most important rule of perception in advertising: the image should be contrasting, concise and clear by composition. de ToulouseLautrec is a prominent representative of impressionism, who has conveyed impressionistic fragmentation of composition to poster, as if a part of the plot is taken from life. The main visual means are line and monochrome saturated elements in contrasting combinations. At the same time, there was a clear division of the genre: bill (affiche) was in the form of a printed text message about the events; poster was a visual message with short text accompaniment.

Unique graphic stylistics was reflected in Art Nouveau. Czech artist Alphonse Mucha living in Paris, France for a long time worked extensively in applied graphics. He, as de Toulouse-Lautrec, was one of the experts who raised commercial and theatrical posters to the level of high art. In his works, Mucha often combined a stylized female figure with decorative elements, flowers and fruits, where the influence of Japanese engraving style was obvious:

"Published in London short-lived magazine "The Poster" (1898-1901) reviewed the best of international poster design, including work by A. Mucha, W. Bradley and J. Hassall. Emerging as the English vogue for collecting posters peaked, it was absorbed by “The Art Collector”" (A. Livingston \& I. Livingston, 2003, p. 176).

Researchers from Germany emphasize significant role of fine art in the development of advertising graphics, especially referring to the Jugendstil (Germ.) as Art Nouveau. Mass production of goods has led to a significant expansion of markets, resulting in increased competition and development of poster. Illustrating 100-year advertising history in Germany, 
Austria and Switzerland, the authors recognize it as a mirror of society, works of art and a means of national identification (Ilgen \& Schindelbeck, 2006). Advertising is examined here in the context of the culture and dramatic growth of commercial art. Very important for us is that history of advertising industry is illustrated by the impact of definite epochs spirits, changes in cultural paradigms, dynamics of visual elements use and typical examples of posters that are given in terms of general advertising aesthetics and their artistic value. On the contrary, the authors describe modern advertising as extremely "flashy". Thus, current vocabulary explains this term originated in ancient world.

The "Poster in Munich" album shows how famous artists Otto Eckmann, Max Liebermann and others worked in the field of poster art (Duvigneau, 1975). In reality, it was more a means of earning money for them than high art. As a provement of the above said, there are few examples in the archives of museums with no evident creative finds in particular as far as artistic skills.

Rapid industrialization during the 19th century in the Russian Empire, and, particularly, in Ukraine was accompanied by quick development of printed advertising. This period is the least studied in terms of so called "assembling" of advertising graphics with various examples, and as to studying its imaging tendencies and typology. The development of poster in Ukraine is of great interest for us, but it is poorly documented. Advertising poster was officially recognized as a fact of culture. In 1897, The World Poster Exhibition under the Society of Arts Promotion was opened in Saint Petersburg, Russia. It became the first public overview of advertising (Pryshchenko, 2018, p. 71).

The growth of competition in the middle of 19th century influenced the thematic variability of the poster. The new qualitative impulse was a result of providing local and national fairs. From the point of view of the composition, there is striking variety of techniques, means, plots, wide range of flora and fauna prototypes, combination of technical and decorative forms based on the principles of allegory and metaphor. Many visual forms in the poster of the pre-revolutionary period (up to 1917) in Ukraine, Russia, the Baltic states were carried out at a high artistic level, which corresponded to consumer characteristics of goods and cultural events.

West European advertising graphics faced significant transformations as symbolism, expressionism, cubism and futurism that influenced new stylistics formation. Art Nouveau and constructivism had the most significant impact on advertising graphics. In the early of 20th century poster and cover art were developed mostly in Art Nouveau style (secession/ jugendstil/liberty/modern), which directly influenced visual language and artistic expression of advertising, forming its own graphic interpretations in combination with motifs related to national, historical and mythological figures. From 1893 to 1964 the illustrated magazine of applied arts The Studio was published in Britain presenting many examples in Art Nouveau style. Artists worked with special interest in the field of decor, cultivating complex curved "pure lines", which were considered as the basic characteristics of this style.

Artistic ideas began their changing with the development of industry and technological progress, and the idea of meaninglessness and simple geometric forms aesthetics appeared at that time. Artist's special vision and sense that he put into his work became more important than fixation of reality. During the 1920s, clear visual design replaced free composition. 
The period of the high avant-garde of the 1910s ended with its plasticity based innovations and philosophy of artistic knowledge of the world. The next generation of artists had new approach to the art through designing the environment and forming a new person due to creation of another way of life. Constructivists Vasyl Yermilov, Vladimir Tatlin, Alexander Rodchenko, Lazar Lysytskyi, Gustav Klutsis, by their search, expressed the worldview of technical period and created new laws of artistic thinking.

Constructivist tendencies were intensified in the 1920s and became the ground for functionalism flourishing based on the principles of beauty, simplicity and benefits integrity in everyday life. Piet Zwart - well-known Dutch constructivist, the poster designer who often used the diagonal compositions (Purvis \& Jong, 2010). His excellent use of colour, typography, composition, and photography are reminiscent of the Bauhaus and his influence on the future generations of graphic designers was significant (Design Is History, 2020).

International style was predominant in the varieties of design throughout the 20th century with its minimalism, straight lines, regular geometric shapes that have not lost their relevance today. Practically the whole Europian creative community was engaged in search of the universal language that would convey new rules of harmony. In contrast to abstract compositions with absence of relevance, functionality and adaptability appreciated by the constructivists, their works showed the tendency to flatness and energetics of active colour compositions.

The constructivist evolution of poster was significantly determined by the new Bauhaus artistic paradigm (1919-2019) of the Higher School of Architecture and Design, which became a cultural symbol of Germany and celebrated its 100th anniversary. Bauhaus artistic paradigm is hardly to overestimate as it had a landmark influence on design and advertising of the 20th century. The history of Bauhaus, has been sufficiently investigated for today. It is obvious due to the foreign publications presented in the bibliographic list (Bauhaus, 2017; Gallo, 1975; Guffey, 2015; Meggs \& Purvis, 2006; Weill, 2004). Nevertherless, stylistic aspects of functionalism remain conceal within contemporary artistic interpretations. Poster borrowed modular grids, geometric modelling, element assembly, a limited colour palette with dominated three basic achromatic colours (white, grey and black) and three basic chromatic colours (yellow, blue and red) using three primary shapes (squares, triangles and circles). Texts, photos and graphic elements were a complete whole presented as a clear and coherent message to buyers. Introduced by László Moholy-Nagy in 1923 combination of typography and photography was suggested as the concept of functional graphics. At once, advertising poster was recognized as a necessary task of the society at that time, its function was carefully studied and design became visually organized.

Austrian designer Herbert Bayer studied and later taught at the Bauhaus, working effectively in graphics, photography and advertising. During 1928-1938, he was art director of Berlin, Germany advertising agency Studio Dorland. Since 1938, Bayer has worked as advertising artist, graphic designer, exhibition designer, art and design consultant in American emigration. Exhibitions under his direction "Bauhaus, 1919-1928" (1938), "Contemporary Art in Advertising" (1945) and "50 Years of the Bauhaus" (1968) were the most interesting events in the United States. His posters demonstrate the best stylistic traditions with saturated plane colors, asymmetry and rhythm of geometric figures (Denscher, 2013). The cultural-artistic foundations 
of Bauhaus functionalism gradually spread throughout the world. Former Bauhaus students opened schools and studios, promoting the main idea "from craft to industrial production" in industrial and graphic design, design of architectural environment. One of the brightest examples is Ulm School of Design in Germany founded in 1953 by Bauhaus graduate Max Bill, famous Swiss artist, architect and designer. Creative methods of modernists became an endless source of later artistic interpretations and experiments.

Art Deco or "American glamour" was another bright stylistic branch with its impressive graphic range of posters, outdoor advertising and movie posters in Europe and the United States. John Held Jr., an American cartoonist, graphic artist and one of the most famous magazine illustrators of the 1920s implemented images of a period of carefree hedonism, wealth, freedom and height of the United States (Heimann, 2003).

Poster was also affected by artistic changes since the World War I. With mysticismbased art expressionists tried to indicate essential laws of nature, using exaggerated colour combinations and deliberately simplified forms. The life of modern civilization was represented by an apocalyptic catastrophe approaching to nature and humanity. Advertising poster borrowed the main means of expressionism - vivid and dull colours, and the power of their emotional impact.

Principles of colour-graphic modeling were similar at European design schools. Thus, common concepts led to creation of international style of Swiss origin. Forms sizes and their proportions became multiples of each other. This caused the establishment of the idea of graphic module. The format of graphic module was organized mostly by modular grid, where the fonts were used without serifs, composition was absolutely claers and concise as for selected elements and colors. The rhythm of elements was one of functioning means of visual formation with rotated stripes of different shades, contrasting colors and tones. They were arranged vertically, horizontally and angle-wise. There was an illusion of movement that excited vision, induces reading and stimulated paying attention to advertising. The font was also influenced by personal trend of graphic designer: letters and words became a bright graphic form and active element of composition.

Ukrainian constructivism is mainly indicated by national character, but this realm is poor reflected in Ukrainian scientific publications. Therefore, the majority of Yermilov's creative works in the 1920s are possibly recognized as poster art. Master was keen on futurism and cubism; especially he was interested in Bauhaus artists' searches. Kharkiv, Ukraine modernist Borys Kosariev is a prominent Ukrainian graphic and theater artist who is considered as "father" of Ukrainian avant-garde. He used techniques of applique, collage and texture search converting real volumes into planes in movie posters, and cooperated with Yermilov, Anatol Petrytskyi, Alexander Khvostenko-Khvostov and others.

In the first third of the 20th century, Ukrainian graphic designers relied on folk arts experience. National traditions such as Byzantinism, Ukrainian Baroque, aesthetic values and folk art symbols appraisal became the basis for creation of characteristis to new Ukrainian graphic arts as the most dynamic form of creativity that fully reflected all changes in artistic trends (Horbachov, 1996).

Stylistic analysis of the Ukrainian avant-garde works reveals that this realm of painting has significantly influenced the evolutionary poster changes in future. Ukrainian artists 
brought rich coloristics in cubist monochrome. In addition, they adopted ingenuousness learned from the collective folk arts such as ceramics, tubes, embroideries, dolls, carpets, Easter eggs, tiles, painting of wedding chests, because, in their opinion, Slavic people expressed their energy in bright major colors. Ukraine can be considered as milestones of innovations in the art of the first half of 20th century, where Kiev, Lviv, Kharkiv, Odessa and Kherson (all cities in Ukraine) were the centers of ideas that subsequently formed the phenomenon of Ukrainian avant-garde.

New trends in art stimulated further development of poster. Cassandre, French artist of Ukrainian origin from Kharkiv, Ukraine outlined goals of that time poster artist as follows: the purpose of painting is inside it, and poster is a means of communication between businessman and consumer. Poster plays the role of a telegrapher without creating information but transmitting it in a clear, distinct and expressive form (Gallo, 1975). In early 1930s Cassandre was already a professional advertiser, contracted in the United States, where Ford Motor Company was one of his customers ordered a series of posters. His posters attract attention by contrasting and concise visual forms and dynamics. Moreover, his posters are associated with the ideas of progress and technical changes of the 20th century.

After World War II, the value of poster as a product of graphics and design has diminished for some time. Poster gave the way to photography and media. Neither economic nor political factors, but technological progress, namely, spread of photography caused this situation. Goods were simply photographed at that time and it was far cheaper than ordering advertising to artists. Lithography became economically unprofitable and was replaced by offset and silkscreen printing, which, however, were unable to reproduce the variety of lithography shades and textures at that time. But later, the art of poster was enriched with original artistic solutions and latest printing technologies. In 1955 pop art, focusing on the new imagery created by the media and advertising, appeared on the market. The artists Andy Warhol, Robert Rauschenberg, Roy Lichtenstein, James Rosenquist brought international fame to American pop art. Their creative pursuits were the most clearly manifested in advertising as saturated plane colours, limited palette, stylized images and active use of outline or silhouette.

In the 1960s, Wolfgang Weingart, a Swiss typographer and designer, passed from a set of metal letters to a photographic set to develop a new image-making technique that allowed to develop new complex textures, patterns and images. Destruction of constructive and functional rules of Swiss international style, spontaniety and experimental search for new means of artistic expression were the main features of this style.

Poster art of Josef Müller-Brockmann, one of the most famous graphic designers, as well as near all representatives of Swiss international style was influenced by the concepts of several different artistic movements, including constructivism, De Stijl, suprematism and Bauhaus (Design Is History, 2020). Müller-Brockmann's theatrical, advertising and social posters represent the ideology of visual forms of functionalism, and later, of the New Wave postmodernism, conceived in European culture. He published book on graphic systems and philosophical design issues with deep analysis of visual communication stylistics, history of poster as an object of graphic design and evidence of the level of social culture development (Müller-Brockmann \& Muller-Brockmann, 2004). 
Tumultuous events of the 20th century escalated the need for a poster as effective and inexpensive means of influencing society with the appropriate images created by the means of advertising graphics. Germany, Switzerland, Austria, Netherlands, France, Italy, Poland, Latvia, Lithuania are main countries that influenced poster development in Europe. Polish magazines Sztuka, Project, Intergraphika, German magazine Neue Werbung, Hungarian Interpressgraphic and Swiss Graphis spread the best achievements of poster designers creative community around the world.

Swiss cultural-imaging poster comprises a wide variety of thematic, historical and geographical narratives; creates a visual archive of aesthetic and social processes of different times. The poster art was developed by such famous graphic artists as Carl Roche, Niklaus Stoecklin, Herbert Leupin, Max Huber, Steff Geissbühler, Armin Hofmann, Bill, Laura Lamm, Rosmarie Tissi. Considering the poster as one of the most effective forms of communication, they vary their works in stylistics from functionalism (rationalism) to expressionism or deliberately naive style ("Childish style").

In Ukrainian poster after World War II, the images of new country with bread, sun, happy female faces were revealed. Generally, it was very close to the picture of Tetyana Yablonska "Bread" (1949). Campaign posters with strong ideologically motivating component and glorifying the flourishing country, persons-creators became the most important at that time. The image of motherland was common to all Ukrainians having distinctive features as proud beauty and power, romanticism, national character and Ukrainian ornaments. Poster artists used images and means of Ukrainian folk art as graphic style basis. Colour conventions, compositional patterns are essential in varieties of decorative and applied arts with circular compositions for plates and symmetrical vertical ones - for towels, carpets. But the ideological expansion of the Soviet Union deprived very quickly all other 14 republics with different worldviews and ethno-cultural traditions. Among them were the Baltics, Moldova, Belarus, Caucasus and Central Asia. Posters' creative landmarks often clashed with Soviet authorities and became virtually forgotten.

Ethno-art traditions were still very noticeable in Ukrainian-language posters of movies, performances, concerts, exhibitions, and cultural events of 1960s:

"Expressiveness, originality, witticism and everything that attracts attention are the forefront of Ukrainian poster. So, brightness, contrast, colour unexpectedness, boldness of composition and drawing are typical for the best bill posters. Advertising poster should not only amaze, but also create an emotional image" (Skljars'ka, 1971, p. 8).

Anti-war, environmental, cultural-spectacular, including theatrical genres of poster were developed for the needs of society despite totalitarianism in the Soviet Union, and particular in Ukraine. Development of poster was facilitated by certain events: the opportunity and free access to information from international reviews, presentation of local artists' own works alongside the works of world-famous masters, as well as the ability of art institutions to teach students properly.

International motives dominated in advertising graphics not only on the territory of the Soviet Union, but also in socialist countries. Poster as an inexpensive and effective media was widely used for state influence and control of citizens in Eastern Europe, as well as the praise of communist allies, reproducing historical and cultural images of that period (Heather, 2014). 
For example, the author of this article observed posters with images of the German Democratic Republic period in the Zeitgeschichtliches Forum Leipzig and saw them strikingly similar to the images of social realism with happy children, hard-working women and heroic menbuilders of communism.

In the 1990s, advertising poster experienced enthusiastic growth and became more metaphorical, philosophical and serial. Poster's topics started revolving around the rethinking of the Soviet past, the war in Afghanistan, the explosion at Chernobyl nuclear power plant, gradually moving from collectivist social realism to individual nationalism. Socioeconomic crisis in Ukraine at the end of 20th century slowed down processes of poster development. First of all, cultural and entertaining (theatrical, circus, concert, exhibition) genres were affected by crisis, but commercial poster with new design solutions, often of not very high artistic quality, was developed. In spite of unfavourable circumstances, poster designers of Kiev, Odessa and Kharkiv Oleh Veklenko, Volodymyr Lesniak, Vitali Shostia, Viktor Bystriakov, Volodymyr Vestak, Oleksandr Mikula, Fedir Hlushchuk made a significant contribution to the development of poster art in Ukraine, paying great attention to ecology. During this period, poster style was significantly influenced by Polish decorativeism with its rich colours, flatness, deliberate primitivism of the author's graphics and fragmentation from one side, and by Bauhaus functionalism with flatness, modular grids as independent elements, emphasized graphics, concise and postmodernism from another side.

Advertising graphics is presented mainly by tourist, commercial and cultural posters, aiming at the development of tourism and trade in Italy, France and Greece, since these countries have identified certain economic problems in the end of 20th century. Various graphic tools in the image of landscapes or famous tourist sites, graphics protected by copyright, national colours in explicit or hidden forms show a large number of stylistic solutions from realism through decorativeism to minimalism.

Berlin Exhibition of the 100 Best Posters annually invites artists, designers, printers, and students from German-speaking countries (Germany, Austria and Switzerland) to present a high poster culture of various thematic orientations to present-time society. 100 best posters are exhibited in Berlin, Essen, Karlsruhe (all cities in Germany), Zürich, Lucerne, Lausanne, Geneva, St. Gallen (all cities in Switzerland), and Vienna, Austria each year. The last few years stylistic solutions have been confidently presented in constructivism, neo-primitivism, minimalism, postmodernism, grunge and pop art. Ethnostylistics is absent at the exhibition, indicating the irrelevance of this topic to developed Western European countries. Moreover, cultural-imaging, social and environmental posters are the most represented there.

Polish poster school deserves special attention as the strongest branch in the European space after the German-Swiss one. During the 20th century all kinds of posters (commercial, political, social) as far as their thematic directions, namely tourist, cultural-imaging, environmental, theatrical and cinema posters were actively developed. Krakow, Warsaw, Lublin (all cities in Poland) and Lviv with their intellectual climate met Bauhaus stylistics restrained, but cultivated national values and romantic traditions that became a source of artistic inspiration (Knorowski, 2016).

In 1980s, when computer technologies were introduced in creating posters around the globe, Polish artists demonstrated graphics protected by copyright, painting skills and 
handwriting fonts, denying photography crucially. It allowed them to use various graphic techniques and materials (gouache, watercolour, ink, pencils, mixed media, applique, collage). Metaphor, grotesque and irony as main creative methods made every poster filled with content and required deep thinking. Among many well known poster artists we will represent Andrzej Klimovski, Tadeusz Gronowski, Mieczysław Szczuka, Henryk Tomaszewski, Ján Savko, Andrzej Krajewski, Jan Lenica, Eric Lipinski, Victor Sadowski, Jerzy Cherniavsky, Monika Starovich, who raised poster, particularly, theatrical and cinema to the level of "visual poetry". Gronowski was one of the first artists who integrated illustration with typography, creating a new form of artistic expression, often demonstrating humor in rendering stories. The history of Poland in posters became "colourful chronicles" that give us the idea of aesthetic tastes and cultural life (Culture.pl, 2020). Poster Museum, Wilanów, a suburb of Warsaw, exhibits the large variety of posters, mostly belong to artists and designers of Eastern Europe, and the Musem of Design, Zürich sets out posters of Western Europe and the United States. The Swiss Association includes posters of designers and artists by many countries, represents a poster art from the mid-19th century to the nowadays and documenting the social events, culture, tourism and product advertising (Schweizer plakatsammlungen SPS, 2020).

Socio-cultural concepts in architecture have a significant impact on the visual imagery and semantics of poster as an object of designing. One of the most famous American architects Charles Jencks formulated principles of postmodern architecture (Dzhenks, 1985), among which are as follows:

1) ambivalence becomes value giving priority to imagination over artistic taste;

2) complexity and contradiction of forms is better than minimalism;

3) the language of architecture is influenced by different types of cultures, so a universal culture based on the principles of radical eclecticism and pluralism is required for design;

4) postmodern architecture needs metaphoric sense bringing us closer to natural and aesthetic problems, and therefore Le Corbusier's metaphor "house is machine for life" loses its relevance;

5) urbanism is characterized by mixing of buildings and inhabitants types, small-apartment planning, collage, the presence of multi-ethnic groups, majority.

The above said is completely relevant to design and advertising. Postmodernism in all its expressions contrasts to modernism. Postmodern philosophers refused the rationalist classical school, designers rejected simplicity and functionality, utilitarianism and standardization of modernism. The invasion of postmodernism was a real shock in the 1970s. It destroyed fundamental ideas of design at that time.

Japanese "adapted" Western style to traditional Japanese art (calligraphy, engravings, poetry), and this synthesis became the essence of Japanese poster, where we see the balance of geometric forms, brevity, abstraction, photomontage, stylistically abient advertising appeals from kitsch to surrealism and destructivism. Particularly in the mid-1990s, after national borders were conciderably opened, the world was ready for the perception of Japanese advertising. In 1996, the jury at Cannes Lions International Festival of Creativity emphasized that this advertising does not need any words, it is a purely visual idea, and it is metaphorical, yet simple, comprehensible and obvious that does not need any further explanation. In addition, it creates a cultural image of Japan. 
Lithuanian, Latvian, Estonian posters, even in the Soviet period, broadcast the culture, art, tourism, and nature with an emphasis on the Baltic ethnic identity. Stylistically, this manifested itself in the dosed use of national colouristics, elements of ornamentation, household items, popularization of folk-art crafts and folk festivals. In 2016 big international retrospective poster exhibition was held at the Mystetskyi Arsenal National Art and Culture Museum Complex (Kiev). The Lithuanian art poster was represented by the works from Stasys Ušinskas, Liudas Vilimas, Vytautas Kaušinis, Juozas Galkus, Juozas Gelguda, Adomas Smetona, Jonas Gudmonas also.

We therefore believe that poster designing today is a system art project activity with the sense of realization aesthetic attitudes and values of society, creation of new forms and development of artistic taste. Poster has fixed semantic meaning and it should be considered not only as cultural phenomenon in fact or as creation of attractive image, but as a derivative product appointed by a set of needs, values and norms of a particular historical period.

Studying characteristics of artistic styles greatly influences understanding of historical processes and, accordingly, proceedings of poster development. In the context of globalization, national cultures face serious challenges and become contradictory, so comparative studies provide generalized results of the analysis of imaging, communicative and creative experience of poster designers. Present day poster is a special form of advertising communications, distributing information-shaped or expressive-suggestive messages of directed nature, contributing to the knowledge of cultural-historical reality, understanding the life of society for the dialogue of cultures through the visualization of objects, phenomena and processes.

Many researchers emphasize a wide range of topics and the variety of problems in poster designing. In addition, they underline the necessity for critical analysis of visual data and the synthesis of disciplines that highlight major tendencies of this new integrative trend (Kudyn \& Lomov, 1987; Shevchenko, 2004; Dydo, 2001; Guffey, 2015; Presbrey, 1929; Wobmann, 2020). Visuals provide a valuable basis for stylistic analysis of poster and its impact on society by images, symbols, ornaments and colours. It is a comprehensive resource for understanding the power of design research and essential source of the development of creative concepts in design. Besides, it provides a link between the ideas and their practical implementation, that is why visual language becomes decisive, transmits the ideas to the target audience and actively influences consciousness of that audience. So, creativity is a way of thinking.

The interlacing of many cultural events, transformation of values, mentality of society, personal worldviews led to transformations of the artistic expression means, caused a large number and variety of style searches in poster. We have identified particular typological and axiological differences in advertising communications of postmodern and post-postmodern periods at the beginning of 21 st century. We revealed that main contradiction of culture now lies between multiculturalism, cosmopolitanism and globalization, which are opposed by deglobalization and localization of advertising, in other words, orientation of advertising on regional consumers. The second decade of 21 st century still retains the value of poster as a primary advertising medium. 


\subsection{Visual means of poster}

Art considerably influenced the development of poster (International Poster Gallery, 19972020; RetroGraphik, 2020). The evolution of poster declares significant role of artistic culture in shaping styles in varieties of design. Socio-cultural space, visual forms and their interconnections in human life are properly organized in the process of poster designing.

Among the visual means of poster we outline photo, graphics and font, and the fourth, most common tool today - a combination of photos, drawings, special computer effects, ornaments with geometric backgrounds arranged in any correlations. Posters are created not only by graphic, but also by painting tools. Many posters exist in a single copy for exhibition or display on the street, in a public place. Typically, present-day poster is a polygraphic embodiment of the original created by designer. Poster influences the audience with a vibrant, conditional, laconic graphic and color scheme, often with decorative expressiveness. Specific means of poster are plane image, conciseness, common symbols, visual metaphors, imagery, spectacular comparisons of colours, scales, points of view, degrees of convention, satirical images, cultural types etc.

The analysis of the problems of visualization made it possible to determine the components of poster. They are as follows: originality, compliance with the status of the product or service, clarity with consumer groups, aesthetics, variability of graphic language, metaphorical thinking. Understanding visual system of art contributes to the development of art-imagery perception and thinking in design and advertising. Comparison of colour-graphic means by stylistic tendencies revealed the necessity for syncretism of visual and semantic elements.

Style in poster designing is art-plastic homogeneity of visual-informative environment and its elements as a whole. Comparative constancy is a special feature of style. Graphics in design works is filled with semantic-symbolic stylistics, which is closely related to the historical general-aesthetic standards, typology and meets the value-aesthetic characteristics. Stylistics is often conceptual, and expresses a creative platform. It is difficult to find an exact imitating any of historical styles in present-day design. More often, artists use only individual details of "grand" styles or take a particular style and interpret it freely within the spirit of modern ideas, using visual aids, the latest materials and technologies, creating eclectic combinations and new aesthetic values. We believe that kitsch is the big aesthetic problem of media-cultural space.

The negative phenomenon of pseudo-nationalization was formed and consolidated: pseudo-Ukrainian, pseudo-Russian, pseudo-Japanese, pseudo-Eastern styles. Though, the ethno motives in AGs should not simply "decorate" advertising products. They should help to look for new national forms of advertising and to save regional cultural values in modern life, because the accelerated globalization pace is bringing the world to the blurring of borders.

Author defines colour as a mean of expressiveness and a weighty component of art style. In cultural context, the new understanding of colour and the using of the term "colour synergetics" are well reasonable. As alternative to globalization processes with their aspiration to standardization and assimilation of cultural peculiarities; processes of self-identification of nations are actualized in design and advertising. One of the directions of design research is examining the influence of ethno-art and, especially colouristic traditions of the contemporary 
design as art project culture. Balance of national and international in design activity and in advertising communications is actual and controversial issue. Target audience research from the point of view of mentality has very big prognosis force in advertising, because psychoemotion peculiarities are already stable indices, spread to the large amount of population. Every country has its own cultural traditions, lack of respect ruins the company's advertising strategy (Pryshchenko, 2018).

\section{Discussion and interpretation of results obtained}

The purpose of poster study was to systematize visual means and to determine their functional and image specificities in the communicative space. The author analyzed the above said in a broad cultural context, emphasizing the art-aesthetic problems of poster as a form of socio-cultural communication. Considering stylistic aspects and tendencies of present-day advertising poster development, the main attention is paid to concretization of composition means with presence of certain artistic style features, national motives and symbols. Foreign researchers indicate also the powerful influence of arts and folk crafts on poster (Heimann, 2003; Nerdinger 1991; Presbrey 1929; Wember 1961). In the end 19th - the first half of 20th century vintage posters of European, Eastern, North and Latin American countries clearly demonstrate the use of ethnic motives. Comparing the ethno-stylistics of different countries, we are see that main promising area for Eastern Europe and Ukraine is the development of advertising platforms, design elements that meet the regional characteristics and requirements of the local consumers (Table 1).

The results reported above indicate a correlation between the past, the present and the future of poster art, in particular:

- the past - vintage posters of European, Eastern, North and Latin American countries of the late 19th - the first half of 20th century demonstrate ethno-stylistics and authorial graphics;

- the present - we are rethinking and reimaging the poster art traditions and graphic techniques of previous centuries, and it can be observed that computer graphics today are often inferior to trend artistic graphics;

- the future - it can be assumed that the principles of visualization in the poster will remain a synthesis of colour harmony, aesthetics, art imagery, originality and clarity of the digital picture.

Table 1. Ethnic motives in the advertising poster (source: created by author)

\begin{tabular}{|c|c|c|}
\hline \multicolumn{3}{|c|}{$\begin{array}{c}\text { Northern region (Scandinavian countries): } \\
\text { ethnic motifs with limited colours range are prevails }\end{array}$} \\
\hline $\begin{array}{c}\text { Western Europe and North } \\
\text { America: international stylistics } \\
\text { is prevails }\end{array}$ & $\begin{array}{c}\text { Eastern Europe and Ukraine: } \\
\text { pseudo-stylistics, kitsch and } \\
\text { eclecticism are prevails }\end{array}$ & $\begin{array}{c}\text { Middle East and Asian } \\
\text { countries: national symbolism } \\
\text { is prevails }\end{array}$ \\
\hline \multicolumn{2}{|c|}{ Southern region (African, Mediterranean and Latin American countries): } \\
ethnic motifs with bright colouristics are prevails
\end{tabular}


Of course, our empirical analysis carried is approximate and the indicated factors should be investigated more deeply, because theater and touristic posters, posters of art exhibitions and major cultural events have historical, artistic and ethnographic value.

\section{Recommendations of the study}

In this paper we presented theoretic-methodological recommendations that are relevant at three levels:

1) conceptual-prognostic level that influences the development of advertising poster as a whole. Poster is conceived as illustration of the level of social culture development and reflection of the value orientations of society, as a significant means of social designing and cultural integration. Comparison of past centuries and the present made it possible to outline the prospects of solving artistic and aesthetic problems of advertising and to identify main factors that allow to predict styles in advertising design in the context of socio-cultural dynamics, such as the development of ethnic style (neofolk) as the actual modernization of folk cultures. The main factors include liberation of many countries from communist ideology, creative use of folk art traditions, national identity search, strengthening of regionalization, changes in value orientations, aesthetic tastes of society and patterns of consumption toward individualization, transformation of mass and elite cultures in united middle type of culture - a popular culture that is in demand in different segments of society;

2) the problematic-theoretical level provides creation of methodological base for study of poster as a product of culture in conditions of socio-cultural transformations after successful implementation of creative ideas. The main approach is considered as an interdisciplinary one using comparative, socio-cultural, axiological and art-critical methods. Poster's scientific retrospective revealed its artistic value and cultural heritage. The analysis of the available publications showed that poster actively conveys social, cultural, and historical development of society. The most famous poster schools creative experience with differences in their styles is analyzed from the above-mentioned positions;

3) the disciplinary level contributes to the development of integrated discipline advertising design, which is a deep study of poster art in the historical dynamics. The effectiveness of visual means in present-day poster is determined by graphic solution, persuasive illustrative, colorful and textual materials, sizes, expressiveness and overall contrast that will allow passersby to distingush advertising quickly at a distance. There is a considerable influence of advertising in the evening due to light, colour and movement. Outdoor advertising is targeted at a large number of people, it is very noticeable in size, but it is not suitable for any product or service - it can be effectively used only where you can present a concise image and short slogan. Therefore, the use of visual means in poster should be determined on focusing at target audience concidering ethno-art traditions. In the nearest future, we need to refocus on more subtle approaches to consumer at cultural-imaging advertising products as more individual, more correct and more aesthetic. 


\section{Conclusions}

An interdisciplinary study of communicative, aesthetic and stylistic aspects of poster allowed to elaborate some theoretical generalizations.

The scientific retrospective of the poster evolution is carried and its art-cultural value is revealed. It is established the 20th century is characterized by dramatic boom of poster as the most popular means of propaganda and a tool for promoting political, social or commercial ideas determined by two World Wars, urbanization, development of all spheres of culture, including tourism, also environmental or social threats, the new goods and services appearance, raising the standard of living of the developed countries. Substantial changes occurred in the visual means of advertising, but in the Soviet period - conformism was a forced position for many advertising artists.

At the beginning of 21 st century, adapting to socio-cultural transformations, poster offers much more than illustrating business offers or designing public spaces and urban environments. Annual exhibitions and professional forums on visual communications and design in Europe, America, and Asia show what a modern poster looks like with the use of means for colour-graphic transformations. Generalization, systematization and classification of empirical material of advertising appeals of the 18th - early the 21 st centuries allowed us to conclude that there is a significant borrowing of fine and decorative arts style attributes by advertising. The most sensitive influence at AGs was made by modern and avant-garde trends - expressionism, cubism, abstractionism, suprematism, neoplasticism, constructivism, as well as social realism, pop art and postmodernism.

Semantic space of the poster image is a visualization of the big concept, of the creative idea, of the generalized reproduction of reality in the art visual form and content, information about an object, an ideal representation of material or imaginary objects and phenomena. The poster image is defined as a visual model on the basis of logical thinking, art-aesthetic perception of form and creative intuition, which is realized in three planes - functional, technological and socio-cultural. Because advertising often borrows images from varieties of art, their creative interpretation and preservation of symbolic meanings are necessary.

The stylistic diversity of the beginning 21 th century, determined by world cultural and artistic processes, demonstrates the diversity in the choice of means of artistic expression from remakes of paintings and descriptions to solely font posters, from artistic experiments with photographs to the latest colour-graphic capabilities of digital technologies, which testifies to a wide range of approaches to the advertising ideas visualization.

Thus, poster was updated as cultural trends medium, as the quintessential interaction of design, marketing and advertising. Considering advertising graphics as a product of culture from bill to present-day poster, and advertising as an effective channel of communication, a holistic view on the art imagery of poster as a reflection of the socio-cultural sphere of society is presented in current study. Poster should have accentuated aesthetics, non-standard vision, and graphic communication and be interesting for the target audience. 


\section{References}

Bauhaus. (2017). Typography. Verlag Bild-Kunst.

Culture.pl. (2020). Polska Szkoła Plakatu. https://culture.pl/pl/artykul/polska-szkola-plakatu

Denscher, B. (2013). The poster and art. Austrian Posters. https://www.austrianposters.at/2013/11/04/ the-poster-and-art/

Design Is History. (2020). Josef Müller-Brockmann: Beethoven. http://www.designishistory.com/1940/ joseph-mueller-brockmann/

Duvigneau, V. (1975). Plakate in München, 1840-1940; eine Dokumentation zu Geschichte und Wesen des Plakats in München aus den Beständen der Plakatsammlung des Münchner Stadtmuseums; Ausstellung im Münchner Stadtmuseum. Verlag Karl M. Lipp.

Dydo, K. (2001). Plakaty: wspolczesne plakaty polskie. Series: Bosz Art. Bosz.

Dzhenks, Ch. (1985). Yazik arkhytekturi postmodernyzma. Stroiyzdat.

Gallo, M. (1975). Geschichte der Plakate. Pawlak.

Guffey, E. E. (2015). Posters: A Global History. Reaktion Books Ltd.

Heimann, J. (Ed.). (2003). All-American Ads 30s. Taschen.

Heather, D. (2014). DDR Posters: The Art of East German Propaganda. Prestel.

Horbachov, D. (1996). Ukrainskyi Avangard 1910-1930 rokiv: albom. Mystetstvo.

Ilgen, V., \& Schindelbeck, D. (2006). Am Anfang war die Litfaßsäule: Illustrierte deutsche Reklamegeschichte. Primus in Wissenschaftliche Buchgesellschaft (WBG).

International Poster Gallery. (1997-2020). A Brief History of the Poster. https://www.internationalposter. com/a-brief-history-of-the-poster/

Knorowski, M. (2016). Polish Poster of 20th Century. Poster Museum. http://www.postermuseum.pl/ en/virtual-museum/

Kudyn, P., \& Lomov, B. (1987). Psykholohyia vospryiatiya i iskusstvo plakata. Plakat.

Livingston, A., \& Livingston, I. (2003). The Thames and Hudson Dictionary of Graphic Design and Designers. Series: Thames and Hudson World of Art. Thames \& Hudson.

Meggs, Ph. B., \& Purvis, A. W. (2006). Megg's History of Graphic Design. John Wiley \& Sons.

Müller-Brockmann, J., \& Muller-Brockmann, Sh. (2004). History of the Poster: Plakat, Affiche, Poster. Phaidon Press.

Nerdinger, F. W. (1991). Die Welt der Werbung. Campus Verlag.

Presbrey, F. (1929). The History and Development of Advertising. Doubleday, Doran \& Company, Inc.

Pryshchenko, S. (2018). Hkudozhn’o-obrazna systema reklamnoyi grafiky. Nacional'na akademija upravlinnja kul'turi i mistectv.

Purvis, A. W., \& Jong, C. W. (2010). Dutch Graphic Design: A Century of Innovations. Thames \& Hudson.

RetroGraphik. (2020). History of poster art. https://retrographik.com/category/arts-movement/

Schweizer plakatsammlungen SPS. (2020). Schweizer plakatsammlungen SPS. http:// schweizerplakatsammlungen.ch/vgksp/

Shevchenko, V. (2004). Kompozytsiya plakata. Koloryt.

Skljars'ka, M. O. (1971). Ukrainskyi radianskyi plakat: albom. Mystetstvo.

Weill, A. (2004). Graphics: A Century of Poster and Advertising Design. Series: New Horizons. Thames \& Hudson.

Wember, P. (1961). Die Jugend der Plakate, 1887-1917. Scherpe.

Wobmann, K. (2020). Die Geschichte des Plakates - vom Mittelalter bis heute. https://poster-auctioneer. com/geschichte 